Acta vet. scand. $1969,10,309-318$.

From the Department of Medicine I, Royal Veterinary College, Stockholm, and the Research Station of the Veterinary Institute, Skara, Sweden.

\title{
BLOOD AND BONE MARROW STUDIES IN CATTLE FEEDING ON BRASSICA SPECIES*)
}

By

A. W. Bäckgren and G. Jönsson

Anaemia is a common finding in ruminants after lengthy feeding on Brassica species.

Most evidence indicates that the anaemia is haemolytic. For a detailed bibliography references should be made to recent works by Grant et al. (1968 a, b). There are still gaps, however, in the train of evidence. No studies of the bone marrow, for example, have been made in conjunction with Brassica feeding.

The fact that it has not been possible to induce anaemia through the feeding of other animal species than ruminants on Brassicae may be interpreted in the manner that elements with haemolytic properties are released or formed on the ruminal breakdown of these feedstuffs. Hypotheses have also been advanced, however, to the effect that, in the breakdown in the rumen, substances are formed which bind or prevent synthesis of the elements which are of significance for the erythropoiesis. Thus Steger et al. (1964) found that the content of vitamin $\mathrm{B}_{2}$ in milk was greatly reduced after feeding on marrow stem kale, which they interpreted in the manner that the feeding caused a disturbance of the microbial equilibrium in the rumen and, among other things, inhibited the function of the vitamin- $\mathrm{B}_{2}$ producing bacteria. The same authors advanced the hypothesis

*) The cost of the investigation was partly borne by The Agricultural Research Council. 
that the high content of hydrosulphuric acid in the rumen, which they found in their feeding experiments, might bind microelements such as copper and cobalt which are essential for the erythropoiesis. But there is no experimental evidence to support this hypothesis.

Ellerström \& Josefsson (1967) discuss the possibility of an induced vitamin $B_{12}$ deficiency as pathogenetic factor in kale anaemia. Split products (isothiocyanates) from some of the thioglucosides occurring in Brassica species have been reported to possess antibiotic properties (McKay et al. 1959). In this way the activity of the $B_{12}$-producing microbes, among others, might be inhibited. The inhibition of the vitamin $B_{12}$ synthesis would be further accentuated by the binding of cobalt - according to the assumption of Steger et al. (1964) - to breakdown products from Brassica species.

The primary purpose of the present investigation was to study the haematopoietic apparatus in the bone marrow in conjunction with rape-feeding. It was also considered worth-while to examine the hypothesis of Ellerström \& Josefsson concerning a vitamin $B_{12}$ deficiency.

\section{MATERIAL AND METHODS}

Sixteen lactating cows were divided into 2 equally large groups, and as similar as possible regarding age, milk production and pregnancy term.

After a transitional period of a week the experimental group was given free access to rape during the 9 weeks of the experiment. The average daily consumption varied between 40 and 60 kg per cow. During the first 4 weeks the experimental group grazed on a lean and the control group on a fairly plentiful pasture. From the 5th week all cows were stabled and the control group was given hay and grass silage. Both groups' rations were supplemented by concentrates (70\% grain, $10 \%$ soya meal, $10 \%$ coco expellers and $10 \%$ ground nut expellers) according to the nutritional requirements of the individual cow. After the end of the experimental period the experimental group received the same feed as the control group.

Samples of the rape were collected once a week and deepfrozen. After the end of the experiment the rhodanid content in 
all samples was determined and found to vary between 2.4 and $3.9 \mathrm{mg}$ per $100 \mathrm{~g}$ sample ${ }^{\star}$ ).

Blood samples were taken once a week from all cows. Bone marrow biopsies were done by sternal puncture before, in the middle of, and at the end of the experimental period. Biopsy could not be performed, however, on 1 cow in each group.

The following estimations were made on heparinized blood and on serum: Haemoglobin, packed cell volume (PCV), erythrocyte count, serum iron according to Allgén \& Odelius (1964); and serum content of vitamin $B_{12}$ according to Hutner et al. (1956). Total and differential white cell counts were performed from experimental week 5 onwards. From the values of haemoglobin, PCV and erythrocyte counts the mean corpuscular haemoglobin ( $\mathrm{MCH})$, the mean corpuscular volume (MCV) and the mean corpuscular haemoglobin concentration (MCHC) were calculated. For the reticulocyte count, staining was done according to Seyfarth (1927).

As regards vitamin $B_{12}$ the determinations were made on deep-frozen serum from 1 sampling during the pre-experimental period and 1 during the last week of the experimental period.

Smears from bone marrow were made by the cover glass method, dried in air and stained with May-Grünwald-Giemsa. On each smear the ratio myeloid : erythroid cells $\left(\frac{M}{E}\right)$ was calculated, and also the maturity ratio for erythroid cells (E), the latter according to the formula:

$$
E=\frac{\text { polychromatic erythroblasts }+ \text { normoblasts }}{\text { proerythroblasts }+ \text { basophilic erythroblasts }}
$$

For each estimation 400 cells were counted.

\section{RESULTS}

The haemoglobin levels, erythrocyte counts and packed cell volumes were on an average somewhat lower in the experimental group during the trial, but there were no significant differences from the control group in any respect or at any time. This is shown in Table 1, which gives the values from every third blood sampling. Nor were there any differences as regards MCV, MCH

*) The determinations were made by Dr. E. Josefsson, Swedish Seed Association, Svalöv, according to the method described by him (Josefsson 1967). 
T a b l e 1. Haemoglobin, packed cell volume and erythrocyte counts of cattle feeding on rape. $\bar{x} \pm s . n=8$ in each group.

\begin{tabular}{|c|c|c|c|c|c|c|}
\hline \multirow{2}{*}{$\begin{array}{l}\text { Experi- } \\
\text { mental } \\
\text { week no. }\end{array}$} & \multicolumn{2}{|c|}{$\mathrm{Hb} \mathrm{g} / 100 \mathrm{ml}$} & \multicolumn{2}{|c|}{$\operatorname{PCV} \%$} & \multicolumn{2}{|c|}{ Erythrocytes $\cdot 10^{6} / \mathrm{mm}^{3}$} \\
\hline & control & rape fed & control & rape fed & control & rape fed \\
\hline-1 & $11.73 \pm 1.12$ & $11.31 \pm 0.71$ & $35.7 \pm 2.4$ & 34.5 & $6.15 \pm 0.50$ & $6.04 \pm 0.26$ \\
\hline 2 & $12.36 \pm 1.05$ & $11.95 \pm 1.10$ & $35.5 \pm 2.3$ & $34.7 \pm 2.6$ & $6.66 \pm 0.70$ & $6.63 \pm 0.59$ \\
\hline 5 & $11.94 \pm 1.20$ & $11.26 \pm 0.90$ & $34.9 \pm 3.0$ & $32.9 \pm 3.4$ & $6.33 \pm 0.70$ & $6.01 \pm 0.60$ \\
\hline 8 & $11.49 \pm 1.01$ & $11.17 \pm 1.42$ & $32.1 \pm 3.3$ & $32.3 \pm 3.9$ & $6.21 \pm 0.84$ & $5.61 \pm 0.83$ \\
\hline 11 & $12.03 \pm 0.59$ & $11.54 \pm 1.21$ & $34.4 \pm 1.9$ & $33.4 \pm 3.8$ & $6.09 \pm 0.53$ & $5.55 \pm 0.40$ \\
\hline
\end{tabular}

T a b l e 2. MCV, MCH and MCHC after feeding with rape.

$\overline{\mathrm{x}} \pm \mathrm{s} . \mathrm{n}=8$ in each group.

\begin{tabular}{|c|c|c|c|c|c|c|}
\hline \multirow{2}{*}{$\begin{array}{l}\text { Experi- } \\
\text { mental } \\
\text { week no. }\end{array}$} & \multicolumn{2}{|c|}{$\mathrm{MCV} \mu^{3}$} & \multicolumn{2}{|c|}{$\mathrm{MCH} \mathrm{g}^{10^{-12}}$} & \multicolumn{2}{|c|}{$\mathrm{MCHC} \%$} \\
\hline & control & rape fed & control & rape fed & control & rape fed \\
\hline-1 & $58.4 \pm 5.0$ & $56.7 \pm 3.8$ & $19.0 \pm 1.5$ & $18.5 \pm 1.1$ & $32.4 \pm 1.7$ & $32.7 \pm 1.4$ \\
\hline 2 & $53.6 \pm 4.7$ & $52.6 \pm 2.2$ & $18.6 \pm 1.4$ & $18.1 \pm 1.0$ & $34.7 \pm 1.0$ & $34.4 \pm 1.2$ \\
\hline 5 & $55.3 \pm 3.2$ & $54.7 \pm 3.9$ & $18.8 \pm 1.3$ & $18.7 \pm 0.8$ & $34.1 \pm 1.3$ & $34.3 \pm 1.4$ \\
\hline 8 & $51.9 \pm 4.3$ & $57.7 \pm 6.3$ & $18.4 \pm 1.4$ & $19.9 \pm 2.0$ & $36.0 \pm 1.9$ & $34.6 \pm 1.5$ \\
\hline 11 & $56.6 \pm 4.7$ & $60.1 \pm 3.6$ & $19.9 \pm 1.7$ & $20.6 \pm 2.0$ & $34.9 \pm 0.7$ & $34.4 \pm 1.4$ \\
\hline
\end{tabular}

or MCHC (Table 2). No reticulocytes were observed on any occasion.

Total and differential white cell counts did not differ between the groups in the later part of the investigation. Thus the average numbers of granulocytes in experimental week 8 were 2290 and 2250 per $\mathrm{mm}^{3}$ in the control and experimental groups, respectively.

Serum iron values were on an average higher in the experimental than in the control group, with the greatest differences at the end of the trial. However, the within-group variation was large and there were no statistically significant differences between the groups. The values for the control and experimental groups were $(\overline{\mathrm{x}} \pm \mathrm{s}) 147 \pm 27$ and $151 \pm 24 \mu \mathrm{g} / 100 \mathrm{ml}$ at the beginning and $159 \pm 45$ and $206 \pm 43 \mu \mathrm{g} / 100 \mathrm{ml}$ at the end of the experiment.

The serum contents of vitamin $B_{12}$ in the 2 groups were $285 \pm 182$ and $183 \pm 58 \mathrm{pg} / \mathrm{ml}$ for the control and experimental groups, respectively, at the beginning of the experiment, $234 \pm 103$ and $229 \pm 65 \mathrm{pg} / \mathrm{ml}$ at its end. There were no significant differences either between groups or between sampling occasions. 


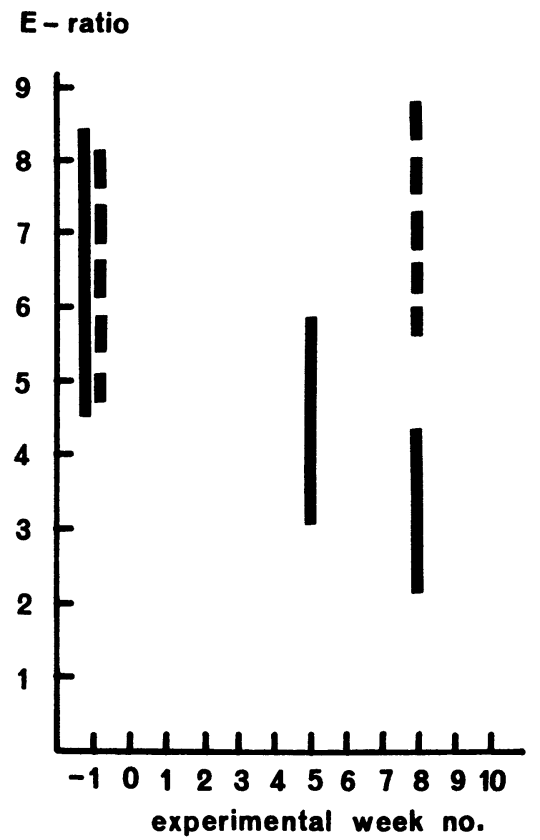

Figure 1. The maturity ratio for erythroid cells (E) in the bone marrow before and during feeding with rape. Filled bars represent the experimental group and broken bars the controls (mean and $95 \%$ confidence limits).

The $\frac{M}{E}$ ratio and the maturity ratio of the erythroid cells in the bone marrow showed a significant decrease in the experimental group during the experiment (Table 3 and Fig. 1).

T able 3. The $\frac{\text { myeloid }}{\text { erythroid }}$ ratio $\left(\frac{M}{E}\right)$ in the bone marrow before and after feeding with rape.

\begin{tabular}{ccccc}
\hline $\begin{array}{c}\text { Experimental } \\
\text { week no. }\end{array}$ & control & P-value & $\begin{array}{c}\text { Experimental } \\
\text { group }\end{array}$ \\
\hline-1 & $\overline{\mathrm{x}}$ & 0.84 & & 1.08 \\
& $\mathrm{~s}$ & $\mathbf{0 . 1 6}$ & n.s. & 0.27 \\
& $\mathrm{n}$ & 7 & & 7 \\
& P-value & n.s. & & $<0.02$ \\
8 & $\overline{\mathrm{x}}$ & $\mathbf{0 . 9 3}$ & & 0.49 \\
& $\mathrm{~s}$ & 0.35 & $<0.02$ & 0.17 \\
& $\mathrm{n}$ & 7 & & 7 \\
\hline
\end{tabular}




\section{DISCUSSION}

In the present study significant differences between experimental and control groups were found only as regards the $\frac{M}{E}$ and $E$ ratios of the bone marrow. The reduced maturity ratio implies that the number of early erythroid precursors constitutes a relatively greater proportion of the erythroid cells in the bone marrow. The drop in the $\frac{M}{E}$ ratio during the experiment indicates that the erythropoiesis was stimulated, as the number of granulocytes in the peripheral blood was not significantly altered. Even if only a qualitative appraisal has been possible the results may be interpreted as a reflection of an increased erythropoietic activity.

Most evidence indicates that the Brassica-induced anaemia is haemolytic. This is suggested particularly by the sporadic occurrence of haemoglobinuria, but also by the reticulocytosis and the Heinz body formation, shown by, among others, Penny et al. (1961), Clegg \& Evans (1962) and Grant et al. (1968 b).

The assumption that the anaemia is haemolytic is supported by the bone marrow changes, strongly indicating an increased erythropoietic activity; in our study, however, the increased breakdown seems to be balanced by the increased erythropoiesis.

No reticulocytosis was found, nor any significant increase of serum Fe consequent on the haemolysis. Both these observations may be explained by the slight extent of the haemolysis. Serum iron, however, is not necessarily elevated in haemolytic anaemia (Videbæk 1965).

A lengthy period of feeding on rape has earlier been found to produce anaemia in ruminants. Schofield (1947) showed that free access to rape produced a macrocytic anaemia in cows within 3 weeks of the start of feeding. Similar observations have been made by others.

In the present study no anaemia was found despite the administration of $40-60 \mathrm{~kg}$ of rape a day for 9 weeks. Thus there appear to be quantitative differences in the anaemia-inducing properties of rape. Local variations and annual variations have earlier been reported as regards the ability of Brassicae to induce a clinically observable disease, particularly haemoglobinuria. The cause of these variations is not known. Different assumptions 
have been advanced concerning the role which the soil, particularly phosphorus deficiency, the occurrence of frost, degree of pigmentation of the plants, may have in this respect (Cote 1944, Evans 1951, Clegg 1967). Even if accessory factors may contribute towards the anaemia, there does not seem to be much sense in speculating about them as long as the main causes of the anaemia-inducing effect of Brassicae given to ruminants are largely unknown. A toxic agent has been assumed to be the main anaemia-inducing factor. It is natural that suspicion has been directed against the thioglucosides, especially the rhodanidogenic, viz. glucobrassicin and neoglucobrassicin. Ellerström \& Josefsson (1967) showed that the variation in the rhodanid content was considerable and that a great part of the variation was genetically determined. A difference in rhodanid content between Brassica species and between different samples of the same species might explain the varying anaemia- and haemoglobinuria-inducing effect found in different studies with these feeds. For example, the rhodanid content of marrow stem kale and rape, grown under the same conditions, was on an average 3.9 and $2.8 \mathrm{mg} / 100 \mathrm{~g}$ sample, respectively (Josefsson, personal communication). There are some evidences indicating a greater anaemia-inducing effect of marrow stem kale than of rape.

Steger et al. (1965) gave potassium rhodanid to cows daily for 14 days. One cow was given $5 \mathrm{~g}$ daily and 2 cows $8 \mathrm{~g}$, one of which also received $30 \mathrm{mg}$ potassium iodide. There was no effect on the red blood picture. In the present study the cows were given about $1.5 \mathrm{~g}$ rhodanid (equivalent to about $2.5 \mathrm{~g}$ potassium rhodanid) daily for 9 weeks. The total administration of rhodanid was thus greater in our study, in which an increased erythropoietic activity entirely compensated for the increased breakdown of erythrocytes. The results of Steger et al. (1965) can therefore not be considered to provide definite evidence that rhodanidogenic glucosides lack an aetiological significance for Brassica-induced anaemia.

In the breakdown of Brassica species in the rumen considerable quantities of hydrosulphuric acid, among other substances, are formed. This has been assumed by Steger et al. (1964) to result in the binding of, for instance, microelements such as copper and cobalt. A lengthy period of feeding results in a decline in the digestibility of these feeds, which was assumed to be the result of a change in the normal equilibrium of the 
ruminal microflora. By this means the synthesis in the rumen of various essential elements, including the vitamin B complex, may be presumed to diminish. These authors have, though not always, observed a reduced content of vitamin $B_{2}$ in the milk, indicating a reduced synthesis of this vitamin. On the same grounds the production of vitamin $B_{12}$ may be presumed to be reduced (Ellerström \& Josefsson). A $\mathrm{B}_{12}$ deficiency in ruminants caused by insufficient administration of cobalt leads to an anaemia which is described by Marston (1952) as macrocytic with marked poikilocytosis and polychromasia. Other authors have characterized it differently and "the anaemia of cobalt deficiency warrants further study" (Underwood 1962). The anaemia due to vitamin $B_{12}$ deficiency in man is megalocytic, usually hyperchromatic, and in that respect, accordingly, of similar type to that found in kale-fed sheep by Grant et al. (1968 b). The present investigations of the serum content of vitamin $B_{12}$, however, showed no difference between experimental and control groups, nor between samples collected before and during the experiment. The method used for $B_{12}$ analyses is admittedly inaccurate, but the results nevertheless indicate that a vitamin $B_{12}$ deficiency has no aetiological significance for the anaemia induced by Brassica species.

\section{ACKNOWLEDGMENTS}

For valuable help and fruitful discussions our thanks are due to Dr. S. O. Berlin, Central Hospital, Skövde, Dr. S. Ellerström, Swedish Seed Association, Svalöv, Dr. Lars Holländer, Central Hospital, Lidköping, Dr. A. Killander, Vitamin $B_{12}$ Laboratory, University Hospital, Uppsala, and Dr. G. Winqvist, Royal Veterinary College, Stockholm.

\section{REFERENCES}

Allgén, L.-G. \& G. Odelius: Serumjärnbestämning med autoanalyzersystem. (Serum iron determination with an autoanalyzer system). Stencil, Beckomberga hospital 1964.

Clegg, F.: Haemoglobinaemia of cattle associated with the feeding of kale and other Brassicae species. Rep. IV Int. Meeting Wld Ass. Buiatrics, Zürich 1967, 184-195.

Clegg, F. C. \& R. K. Evans: Haemoglobinaemia of cattle associated with feeding of Brassicae species. Vet. Rec. 1962, 74, 1169-1176.

Coté, F. T.: Rape poisoning in cattle. Canad. J. comp. Med. 1944, 8, $38-41$.

Ellerstrom, S. \& E. Josefsson: Selection for low content of rhodanidogenic glucosides in fodder rape. Z. Pflanzenzücht. 1967, $\check{8}$, $128-135$. 
Evans, E. T. R.: Kale and rape poisoning in cattle. Vet. Rec. 1951, 63, $348-349$.

Grant, C. A., P. Holtenius, G. Jönsson \& C. B. Thorell: Kale anaemia in ruminants. I. Survey of the literature and experimental induction of kale anaemia in lactating cows. Acta vet. scand. 1968 a, 9, 126-140.

Grant, C. A., P. Holtenius, G. Jönsson, J. Luthman \& C. B. Thorell: Kale anaemia in ruminants. II. Observations on kale-fed sheep. Acta vet. scand. $1968 \mathrm{~b}, 9,141-150$.

Hutner, S. H., M. K. Bach \& G. J. M. Ross: A sugar-containing basal medium for vitamin $\mathrm{B}_{12}$-assay with Euglena; application to body fluids. J. Protozool. 1956, 3, 101-112.

Josefsson, E.: Content of rhodanidogenic glucosides in some Brassica crops. J. Sci. Food Agric. 1967, 18, 492-495.

Marston, H. R.: Cobalt, copper and molybdenum in the nutrition of animals and plants. Physiol. Rev. 1952, 32, 66-121.

McKay, A. F., D. L. Garmaise, R. Gaudry, H. A. Baker, G. Y. Paris, R. W. Kay, G. E. Just \& R. Schwartz: Bacteriostats. II. The chemical and bacteriostatic properties of isothiocyanates and their derivatives. J. Amer. chem. Soc. 1959, 81, 4328-4335.

Penny, R. H. C., J. E. David \& A. J. Wright: Heinz-Ehrlich bodies associated with kale feeding. Vet. Rec. 1961, 73, 747-748.

Schofield, F. W.: The constant occurrence of macrocytic anemia in cattle feeding on rape. Rep. Ontario Vet. Coll. 1947, 29, 122125.

Seyfarth, C.: Experimentelle und klinische Untersuchungen über die vitalfärbbaren Erythrocyten. (Experimental and clinical investigations on intravitally stainable erythrocytes). Folia haemat. (Frankfurt) 1927, 34, 7-38.

Steger, H., B. Piatkowski, B. Busch \& F. Püschel: Intensive Markstammkohlfütterung und ihr Einfluss auf Verdaulichkeit, Blutbild sowie Blut-, Milch- und Harnbestandteile von Kühen, Ochsen und Schafen. (Intense feeding on marrow stem kale and its influence on digestibility, blood cell picture as well as on components of blood, milk and urine of cows, oxes and sheep). Arch. Tierernähr. 1964, 14, 113-126.

Steger, H., B. Piatkowski \& F. Püschel: Über die Wirkung von Thiocyanat auf den Stoffwechsel der Milchkühe. (On the effect of thiocyanate on the metabolism of dairy cows). Arch. Tierernähr. 1965, 15, 399-405.

Underwood, E. J.: Trace elements in human and animal nutrition. Acadentic Press, New York and London 1962.

Videbæk, Aa.: Haematologi. (Haematology). Munksgaard, Copenhagen 1965.

\section{SUMMARY}

Daily administration of $40-60 \mathrm{~kg}$ rape for 9 weeks to 8 cows produced no changes in the red blood picture. On the other hand a reduction of the myeloid:erythroid ratio and the maturity ratio of the 
erythroid cells of the bone marrow was found. This is interpreted as a sign of increased erythropoiesis. The Brassica-induced anaemia found in other investigations is assumed on several grounds to be haemolytic. The present study confirms this assumption, the increased breakdown of erythrocytes being entirely compensated by an increased erythropoiesis. The difference between the present and earlier reports, in which anaemia was found after a shorter time of feeding on roughly the same quantities of rape, is discussed, one possible explanation being that differences exist in rhodanid content between Brassica species.

\section{ZUSAMMENFASSUNG}

Untersuchungen von Blut und Knochenmark von Kühen, die mit Brassica-Arten gefüttert wurden.

Tägliche Verabreichung von 40-60 kg Raps während 9 Wochen an 8 Kühe bewirkte keine Veränderungen im roten Blutbild. Dagegen wurde festgestellt, dass die Myeloid-erythroidquote und die Reifequote der erythroiden Zellen im Knochenmark geringer wurden. Dies wird gedeutet als Zeichen einer gesteigerten Erythropoese. Die in anderen Untersuchungen festgestellte, Brassica-bewirkte Anämie wird aus mehreren Gründen als hämolytisch angesehen. Das vorliegende Untersuchungsergebnis, bei dem der gesteigerte Erythrozytenabbau völlig durch eine gesteigerte Erythropoese ausgeglichen wurde, stützt diese Annahme. Der Unterschied zwischen diesem Ergebnis und den früheren Ergebnissen, bei denen Anämie konstatiert wurde bei Fütterung von ungefähr derselben Quantität Raps während kürzerer Zeit, wird diskutiert, und man betont u.a., dass Unterschiede im Rhodanidgehalt zwischen verschiedenen Brassica-Arten eine mögliche Erklärung sei.

\section{SAMMANFATTNING \\ Undersökningar av blod och benmarg från kor utfodrade med Brassica-arter.}

Daglig tillförsel av $40-60 \mathrm{~kg}$ raps under 9 veckor åt $8 \mathrm{kor}$ gav inte några förändringar $\mathrm{i}$ den röda blodbilden. Däremot konstaterades en minskad myeloid-erytroidkvot samt en minskad mognadskvot hos de erytroida cellerna i benmärgen. Detta tolkas som tecken på en ökad erythropoes. Den i andra undersökningar konstaterade Brassicainducerade anämien antages av flera skäl vara hämolytisk. Föreliggande undersökningsresultat styrker detta antagande, varvid den ökade erythrocytnedbrytningen helt kompenserats av en ökad erythropoes. Skillnaden mellan föreliggande resultat och tidigare rapporterade, vid vilka anämi konstaterats vid kortare tids utfodring med ungefär samma mängder raps, diskuteras, varvid bl. a. framhålles att skillnader i rhodanidhalt mellan olika Brassica-arter kan vara en möjlig förklaring. 